\title{
Plasma Levels of HDL and Carotenoids are Lower in Dementia Patients with Vascular Comorbidities
}

\author{
Irundika H.K. Dias ${ }^{\mathrm{a}}$, Maria Cristina Polidori ${ }^{\mathrm{b}, \mathrm{c}, *}, \mathrm{Li} \mathrm{Li}^{\mathrm{a}}$, Daniela Weber ${ }^{\mathrm{d}}$, Wilhelm Stahl ${ }^{\mathrm{b}}$, \\ Gereon Nelles ${ }^{\mathrm{e}}$, Tilman Grune ${ }^{\mathrm{d}}$ and Helen R. Griffiths ${ }^{\mathrm{a}, *}$ \\ ${ }^{\mathrm{a}}$ Life and Health Sciences and Aston Research Centre for Healthy Ageing, Aston University, Birmingham, UK \\ ${ }^{\mathrm{b}}$ Institute of Biochemistry and Molecular Biology I, Heinrich-Heine-University, Duesseldorf, Germany \\ ${ }^{\mathrm{c}}$ Institute of Geriatrics, University of Cologne, Köln, Germany \\ ${ }^{\mathrm{d}}$ University of Jena, Jena, Germany \\ ${ }^{\mathrm{e}}$ NeuroMed, MedCampus Hohenlind Cologne, Köln, Germany
}

Handling Associate Editor: Jack de la Torre

Accepted 27 November 2013

\begin{abstract}
Elevated serum cholesterol concentrations in mid-life increase risk for Alzheimer's disease (AD) in later life. However, lower concentrations of cholesterol-carrying high density lipoprotein (HDL) and its principal apolipoprotein A1 (ApoA1) correlate with increased risk for AD. As HDL transports oxocarotenoids, which are scavengers of peroxynitrite, we have investigated the hypothesis that lower HDL and oxocarotenoid concentrations during AD may render HDL susceptible to nitration and oxidation and in turn reduce the efficiency of reverse cholesterol transport (RCT) from lipid-laden cells. Fasting blood samples were obtained from subjects with 1) AD without cardiovascular comorbidities and risk factors (AD); 2) AD with cardiovascular comorbidities and risk factors (AD Plus); 3) normal cognitive function; for carotenoid determination by HPLC, analysis of HDL nitration and oxidation by ELISA, and ${ }^{3} \mathrm{H}$-cholesterol export to isolated HDL. HDL concentration in the plasma from AD Plus patients was significantly lower compared to AD or control subject HDL levels. Similarly, lutein, lycopene, and zeaxanthin concentrations were significantly lower in AD Plus patients compared to those in control subjects or AD patients, and oxocarotenoid concentrations correlated with Mini-Mental State Examination scores. At equivalent concentrations of ApoA1, HDL isolated from all subjects irrespective of diagnosis was equally effective at mediating RCT. HDL concentration is lower in AD Plus patients' plasma and thus capacity for RCT is compromised. In contrast, HDL from patients with AD-only was not different in concentration, modifications, or function from HDL of healthy age-matched donors. The relative importance of elevating HDL alone compared with elevating carotenoids alone or elevating both to reduce risk for dementia should be investigated in patients with early signs of dementia.
\end{abstract}

Keywords: Aging, Alzheimer's disease, free radical scavenger, 3-nitrotyrosine, protein carbonyl formation, protein oxidation

\footnotetext{
${ }^{*}$ Correspondence to: M.C. Polidori, Institute of Geriatrics, University of Cologne, Köln, Germany. Tel.: +49 0221 16292303; Fax: +49 0221 16292306; E-mail: maria.polidori-nelles@uk-koeln.de; H.R. Griffiths, Life and Health Sciences, Aston University, Birmingham, UK. Tel.: +44 0121204 3950; Fax: +44 0121 359; E-mail: h.r.griffiths@aston.ac.uk.
}

\section{INTRODUCTION}

Aging is the major risk factor for dementia. Prevalence rates across the world are estimated to lie between $5.9-9.4 \%$ for people aged over 65 with a third of the $>85$ year old population affected. Correspondingly, absolute incidence of age-related pathologies particularly Alzheimer's disease (AD) is increasing [1]. 
$\mathrm{AD}$ represents at least $70 \%$ of dementia cases and is characterized by progressive neurodegenerative alterations, gradually reducing cognitive performance with loss of memory, orientation, and judgment. Loss of synapses and cholinergic neurons, accumulation of extracellular amyloid- $\beta(\mathrm{A} \beta)$ plaques, and intraneuronal neurofibrillary tangles of hyperphosphorylated tau are major hallmarks of AD brain and are implicated in its pathogenesis. There is accumulating evidence that vascular pathology plays a central role in dementia onset and development, and some important information from recent reanalyses include data from a $75+$ year-old community cohort in which $49 \%$ of the AD cases clinically diagnosed on the basis of the NINCDS-ADRDA criteria showed a possible vascular component [2]. The next most prevalent dementia, vascular dementia $(\mathrm{VaD})$, is characterized by macroangiopathy and is often present as a post-stroke dementia with overlapping traditional hallmarks of AD including $A \beta$ accumulation. This and other information is certainly very important to the clarification of vasculartargeted preventive strategies.

Despite the increasing attention on vascular causes of $\mathrm{AD}$, its etiology remains unclear; neither genes nor environment alone are sufficient to explain the onset of $\mathrm{AD}$ in the majority of the population. Cumulative and combined exposures to different risk factors appear to modify dementia risk [3]. The $A P O E \varepsilon 4$ allele is a wellestablished risk factor for late-onset and early-onset forms but $A P O E \varepsilon 4$ is neither a prerequisite for, nor sufficient to cause, AD [4]. Several other polymorphisms have been identified from genome-wide association studies that associate $\mathrm{AD}$ with lipid metabolism including ABCA1, hepatic lipase, and ABCA7 [5, 6]. A number of comorbidities have also been associated with increased risk of developing dementia and share a common dyslipidemic and metabolic phenotype including hypercholesterolemia and type 2 diabetes [7]. Evidence from cross-sectional and observational studies supports an association between elevated serum cholesterol in mid-life and later development of $\mathrm{AD}$ [8]. We have shown previously that low density lipoprotein (LDL) oxidation in AD patients with cardiovascular comorbidities and risk factors correlates with the degree of cognitive impairment [9]. However, statins have not ameliorated $\mathrm{AD}$ in trials and there is insufficient understanding presently to recommend statin interventions to reduce disease risk [10].

Nevertheless, cholesterol transport and metabolism in the brain appears to be important for the development of AD; the centrally oxidized cholesterol product, 24 s-hydroxycholesterol, is an effective inhibitor of
A $\beta$ formation [11]. Despite distinctive compartmentalization of cholesterol metabolism between the brain and the periphery, oxidized lipids may cross-over the blood-brain barrier. Systemically oxidized cholesterol, 27-hydroxycholesterol, can be transported from the periphery across the blood-brain barrier and is increased in the AD brain [12]. Indeed, an increased ratio of $27: 24$ s-hydroxycholesterol has been proposed to favor the formation of $A \beta$ [13].

Studies on the structure of the major variant apoprotein of LDL ApoE- $\varepsilon 4$ which associates with $\mathrm{AD}$ suggest that it may promote $A \beta$ deposition, decreases plaque clearance, has low antioxidant-like activity, and effects cholinergic dysfunction in AD [14]. Moreover, an increase in membrane cholesterol, especially in lipid rafts, may upregulate the $\beta$-secretase pathway, leading to the accumulation of $A \beta_{40}$ and $A \beta_{42}$ and the increased formation of extracellular amyloid deposits [15]. In contrast, the concentration of plasma highdensity lipoproteins (HDL) is inversely related to the risk of cardiovascular disease and dementia [16]. The atheroprotective effect of HDL is largely attributed to its key role in reverse cholesterol transport (RCT) where excess cholesterol is exported from peripheral cells via $\mathrm{ABCA} 1$ and is subsequently transported back to the liver for excretion [17]. Recent studies have suggested that RCT by HDL from AD patients is impaired and ABCA1-mediated RCT has been shown to act as an important $A \beta$ clearance mechanism in $A p o E-\varepsilon 4$ mice, where ABCA1 deficiency in mice promotes amyloid deposition [18]. ApoA1 is the major apoprotein associated with HDL and it is prone to nitration, chlorination, and oxidation by myeloperoxidase [19, 20]. Homocysteine $(\mathrm{HCy})$ is frequently elevated in dementia and we have shown previously that it is a powerful inducer of LDL apoprotein oxidation [9, 21]. Chlorination of tyrosine 192 and oxidation of the single methionine residue at position 158 in ApoA1 have been associated with impaired RCT $[22,23]$. The aforementioned evidence suggests that modification to ApoA1 on HDL may contribute to impaired RCT in AD.

Healthy diets in general and the Mediterranean regimen in particular reduce the risk for and mortality from AD [24]. Several studies have shown that carotenoids reduce $A \beta$ accumulation and tau hyperphosphorylation and microglial and astrocyte activation in animal models [25]. In addition, patients with moderate to severe dementia have lower plasma levels of two major carotenoids, lutein and lycopene, compared to patients with mild $\mathrm{AD}$ or controls, and among $\mathrm{AD}$ patients a lower Mini-Mental State Examination (MMSE) score was associated with lower lutein and lycopene levels 
$[26,27]$. Carotenoids are lipophilic and are transported by lipoproteins, and the oxo-carotenoids are mainly associated with HDL [28]. They are potent scavengers of peroxynitrite and singlet oxygen, therefore their depletion in dementia may promote post-translational modifications to circulating proteins such as ApoA1 on HDL and impair RCT. We have shown previously that a decrease of circulating carotenoids and tocopherols after correction for fruit and vegetable intake is associated with increased protein oxidation in patients with dementia [29]. Therefore we have investigated the hypothesis that oxocarotenoid depletion in dementia may render HDL more susceptible to nitration and modified HDL may reduce the efficiency of RCT from lipid-laden cells.

\section{MATERIALS AND METHODS}

\section{Subject recruitment}

Seventy seven community dwelling subjects were recruited from the Neurology Outpatient Clinic NeuroMed in Cologne, Germany. Patients were recruited after diagnosis with AD using NINCDS-ADRDA criteria either in the presence of vascular comorbidities and risk factors (elevated intima-media thickness of the common carotid artery and/or type 2 diabetes mellitus) (AD Plus group) or without cardiovascular comorbidities and risk factors (AD group) [9]. Control subjects showed no evidence of cognitive impairment and had no vascular comorbidities and risk factors. Informed consent was obtained from the patients or their caregivers according to severity of disease. Smokers as well as subjects taking medications and/or antioxidant/vitamin/iron supplements were excluded from the study. Patients with secondary dementias or with ongoing acute diseases were also excluded. The patient demographics are reported in Table 1.
Subjects underwent full physical/neurological examination as well as collection of medical history to assess clinical conditions and of nutritional status by means of a qualitative food-frequency questionnaire modified to assess daily intake of fruits and vegetables [27]. An ECG, two consecutive measurements of blood pressure, a carotid duplex sonography as well as the MMSE were performed in all subjects.

\section{Blood sampling and measurements}

This investigation conforms to the principles outlined in the Declaration of Helsinki and according to local ethical committee approval. After informed consent, fasting blood was collected from the antecubital vein into EDTA tubes and kept on ice until centrifugation within $2 \mathrm{~h}$ of collection. Plasma was frozen at $-80^{\circ} \mathrm{C}$ until analysis. Plasma samples were coded and analysis was carried out in a blind fashion.

\section{$H D L$ isolation and quantitation}

Cholesterol concentrations were measured enzymatically with CHOD-PAP kits from Randox, Ireland. Each assay included appropriate standards and calibrators. HDL was separated from the plasma by precipitation with dextran sulphate and magnesium chloride.

For RCT studies, HDL fractions were separated from plasma by density gradient gel electrophoresis according to the method of Chung et al. [30] and purity confirmed by agarose gel electrophoresis. Patient and control HDL nitration was determined by ELISA according to Weber et al. [31].

\section{Plasma carotenoid analysis}

Lycopene, $\beta$-carotene, $\alpha$-carotene, lutein, zeaxanthin, and cryptoxanthin were determined by HPLC according to Stahl et al. [32].

Table 1

Demographic profile of dementia patients and controls

\begin{tabular}{lccc}
\hline Group $(n)$ & Control $(n=33)$ & AD $(n=27)$ & AD Plus $(n=16)$ \\
\hline Average age (mean +SD) & $73.2 \pm 8.3$ & $80.5 \pm 5.7$ & $79.4 \pm 4.7$ \\
Gender $(\%$ male) & 33.3 & $17.1 \pm 8.0$ & 43.7 \\
MMSE score (mean + SD) & $29.0 \pm 4.7$ & $0 \%$ & $19.5 \pm 4.9$ \\
ApoE $\varepsilon 2 / \varepsilon 2$ & $0 \%$ & $15 \%$ & $<1 \%$ \\
ApoE $\varepsilon 2 / \varepsilon 3$ & $21 \%$ & $50 \%$ & \\
ApoE $\varepsilon 3 / \varepsilon 3$ & $70 \%$ & $23 \%$ & $1 \%$ \\
ApoE $\varepsilon 3 / \varepsilon 4$ & $10 \%$ & $12 \%$ & $19 \%$ \\
ApoE $\varepsilon 4 / \varepsilon 4$ & $0 \%$ & $29 \%$ & $12 \%$ \\
$\%$ with hypertension & $24 \%$ & $23.8+2$ & \\
Body mass index Kg/m 2 & $24.1+1.5$ & $129.5+40.6$ & $25.5+1.4$ \\
LDL cholesterol $(\mathrm{mg} / \mathrm{dL})$ & $140.9+53.1$ & & $119+41.4$ \\
\hline
\end{tabular}




\section{In vitro $H D L$ nitration and analysis}

HDL $(200 \mu \mathrm{g} / \mathrm{ml})$ was incubated with the NO donor, spermine NONOate $(30 \mu \mathrm{M})$ in the presence or absence of homocysteine at $37^{\circ} \mathrm{C}$ in the absence or presence of $10 \mu \mathrm{M}$ copper for $16 \mathrm{~h}$. Oxidative reactions were terminated by the addition of DPTA. Five micrograms of HDL was lyophilized to dryness, and dissolved in $20 \mu \mathrm{l}$ of $8 \mathrm{M}$ urea/25 $\mathrm{mM}$ ammonium bicarbonate, $\mathrm{pH} 8.0$, diluted further to lower urea concentration and digested with trypsin (1:50 protease to protein ratio) at $37^{\circ} \mathrm{C}$ for $4 \mathrm{~h}$. The tryptic peptide pool was lyophilized to dryness, dissolved in $0.5 \%$ acetic acid, and analyzed by RP-HPLC-MS/MS on a Surveyor HPLC system and a $0.075 \times 100 \mathrm{~mm} \mathrm{C18} \mathrm{RP} \mathrm{column} \mathrm{(Proxeon),} \mathrm{at}$ $\approx 1.5 \mu \mathrm{l} / \mathrm{min}$, connected online via nano-electrospray with a LXQ linear ion trap mass spectrometer (ThermoFisher). Solvents were $99.5 \%$ water and $0.5 \%$ acetic acid (buffer $\mathrm{A}$ ) and $90 \%$ acetonitrile, $9.5 \%$ water, and $0.5 \%$ acetic acid (buffer B). Peptides were eluted over a 90 -min gradient from $5 \%$ to $60 \%$ solvent B and monitored by data dependent analysis MS/MS scans for the masses corresponding to tyrosine nitration and methionine oxidation $(+45,+16$ respectively).

\section{Western blot}

HDL nitration and ABCA1 expression in differentiated THP1 cells were assessed by western blotting.

Protein samples from $\mathrm{NO} / \mathrm{HCy} / \mathrm{Cu}$-modified HDL or differentiated THP-1 cells $(10 \mu \mathrm{g})$ were separated by $1 \mathrm{D}$ SDS-PAGE (12.5\% gel) and electroblotted onto polyvinylidene fluoride (PVDF) membrane. After electroblotting at $20 \mathrm{~mA}$ for $16 \mathrm{~h}$, membranes were blocked in Tween $20(1 \%)$ Tris Buffered Saline (TTBS) containing $3 \%$ bovine serum albumin (BSA) for $2 \mathrm{~h}$. Membranes were incubated with either mouse monoclonal antibody against 3-nitrotyrosine or anti-ABCA1 (1:1000) overnight. The membranes were washed with TTBS $(6 \times 15 \mathrm{~min})$ before incubation with a peroxidase conjugated secondary antibody (Sigma Aldrich, Poole, UK) for $2 \mathrm{~h}(1: 4000)$ peroxidase conjugated anti goat $\mathrm{IgG}$ (diluted in TTBS containing $0.3 \%$ BSA). Membranes were rinsed in TBS $(6 \times 15 \mathrm{~min})$ and then a chemiluminescent substrate (ECL Plus, Little Chalfont, Amersham Biosciences) was used to visualize detected proteins. The images recorded using a GS 710 calibrated imaging densitometer. Bands were analyzed and quantified using Scion software (NIH, USA).

\section{Carbonyl and 3-nitrotyrosine ELISAs}

To determine protein oxidation and nitration in plasma proteins and in HDL isolated by density gra- dient centrifugation, proteins were diluted to $10 \mu \mathrm{g}$ $/ \mathrm{ml}$ carbonate buffer prior to analysis by ELISA as previously described $[31,33]$.

\section{Differentiation protocol}

Human THP-1 monocyte cells were seeded into six-well plate at $1.8 \times 10^{6}$ cells per well in RPMI 1640 medium + GlutaMAX ${ }^{\mathrm{TM}} 1$ containing bovine fetal serum $(10 \%, \mathrm{v} / \mathrm{v})$, penicillin $(50 \mathrm{unit} / \mathrm{ml})$, and streptomycin $(50 \mu \mathrm{g} / \mathrm{ml})$. Cells were differentiated into macrophages in the presence of phorbol 12-myristate 13-acetate (PMA, $100 \mathrm{ng} / \mathrm{ml}$ ) for 5 days and medium was replaced at least every $48 \mathrm{~h}$.

\section{Reverse cholesterol transport}

Macrophages were transformed into foam cells by incubation with oxidized LDL $(50 \mu \mathrm{g} / \mathrm{ml})$ in serum free medium containing BSA $(1.5 \%$, w/v) for $48 \mathrm{~h}$ including $\left[{ }^{3} \mathrm{H}\right]$-cholesterol $(0.1 \mu \mathrm{Ci} / \mathrm{ml})$. The medium was then removed and the cells were washed and incubated in serum free medium with BSA $(1.5 \%$, w/v), ApoA1 $(10 \mu \mathrm{g} / \mathrm{ml})$, or HDL $(10 \mu \mathrm{g} / \mathrm{ml})$ for $24 \mathrm{~h}$ to determine efflux.

The supernatant was collected and cells were washed, retaining the supernatant for further analysis. The entire pellet was lysed with $1 \mathrm{ml} 20 \%$ triton-X100 and $5 \mathrm{ml}$ Optiphase 'Hisafe' 3 liquid scintillation cocktail was added before radioactivity determination.

\section{RESULTS}

Patients in the AD Plus group had significantly higher body mass index $(p<0.05)$ than control subjects and hypertension was twice as frequent; however, LDL cholesterol was not different between groups (Table 1). The $A P O E \varepsilon 4$ allele was present in $\mathrm{AD}$ and $\mathrm{AD}$ Plus patients at three times the frequency of control subjects (Table 1). HDL cholesterol was lower in AD Plus patients but not in the plasma from patients with $A D$ when compared with control subjects (Fig. 1A). Similarly, analysis of plasma carotenoid levels revealed that lutein, lycopene, and zeaxanthin concentrations were significantly lower in the AD Plus group but not in control subjects or AD patients (Figs. 1B-D). However, $\beta$-carotene, $\alpha$-carotene, and cryptoxanthin were not significantly different between any of the patient groups and controls (data not shown). MMSE correlated positively with plasma HDL, lutein, and zeaxanthin but not lycopene, $\beta$-carotene, $\alpha$-carotene, and cryptoxanthin. As HDL is the principal carrier of 

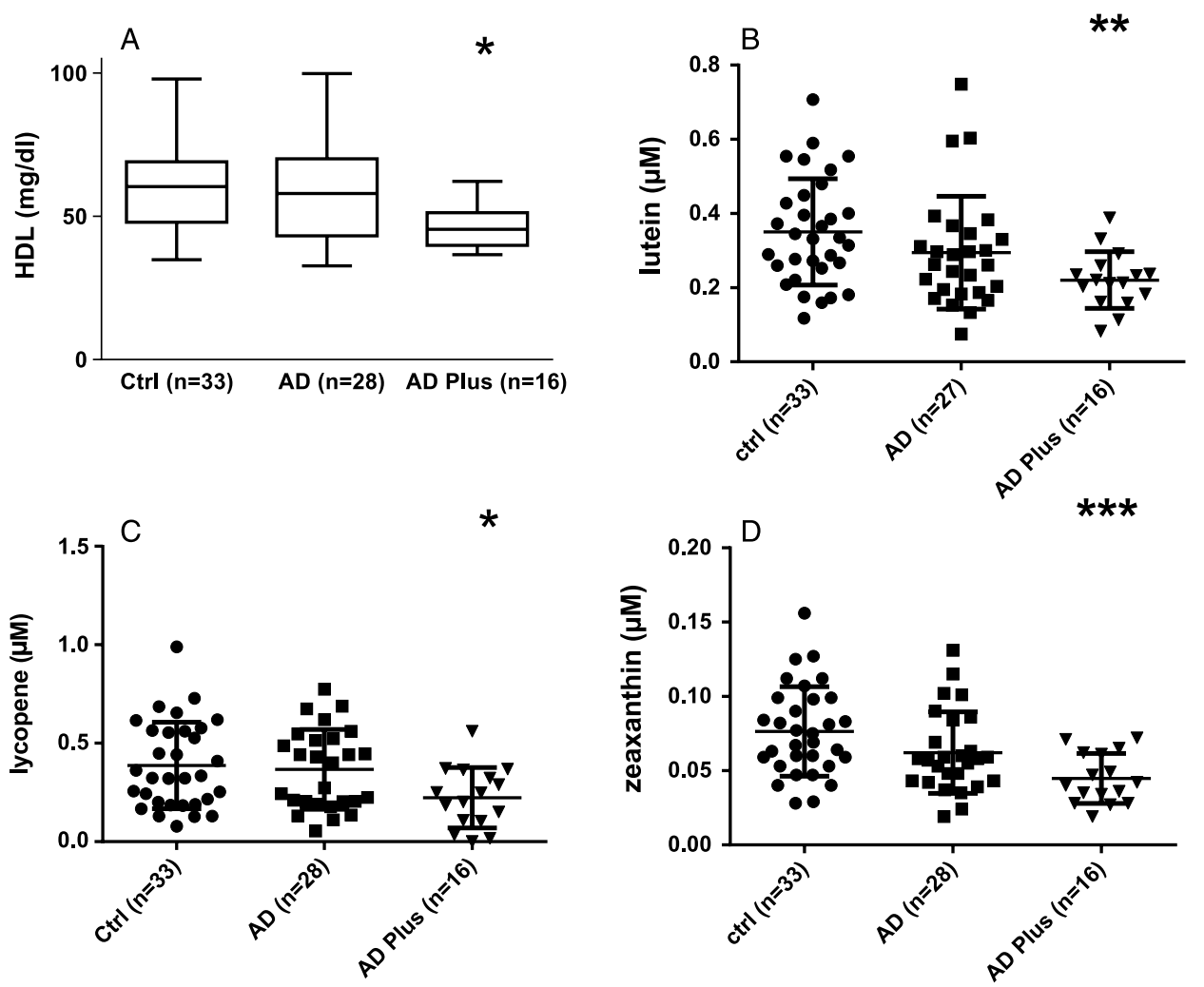

Fig. 1. Plasma HDL and carotenoids are depleted in AD Plus. A) HDL cholesterol concentration (mg/dl) was analyzed in plasma from patients with $\mathrm{AD}, \mathrm{AD}$ Plus, and age-matched control subjects by dextran sulfate-magnesium precipitation using Randox kit. Plasma lutein (B), lycopene (C), and zeaxanthin (D) were determined in plasma from patients in the AD group, AD Plus group, and age-matched control subjects by HPLC. Data are expressed as mean and $95 \%$ confidence interval and differences were evaluated by ANOVA where ${ }^{*} p<0.05 ;{ }^{* *} p<0.01 ;$ and ${ }^{* * *} p<0.005$.

specific carotenoids including lutein and zeaxanthin, it may be anticipated that lower plasma carotenoid concentrations mirror the reduction in plasma HDL concentration. However, the correlations of both zeaxanthin and lutein with MMSE were maintained after correcting the carotenoid concentration per mole of HDL cholesterol.

Nitration of ApoA1 and HDL was induced by homocysteine/nitric oxide and copper oxidation (Fig. 2A). HDL carbonyl content was elevated in the presence of homocysteine and copper, and was attenuated by the presence of spermine NONOate (Fig. 2B). Conversely, protein nitration was increased when HDL was co-incubated with homocysteine, spermine NONOate, and copper. By MS, three oxidized methionine containing peptides were present ETEGLRQEM*SKDLEEVK, $K W Q E E M^{*} E L Y R, L S P L G E E M^{*} R$ corresponding to methionine 86, 112 and 148; and one nitrated peptide $L A E Y^{*} H A K A T E H L S T L S E K$ corresponding to tyrosine nitration at position 192 was identified. RCT from cholesterol-loaded macrophages was diminished after modification to HDL by homocysteine, copper with and without spermine nonoate (Fig. 2C). However, for HDL isolated from patient and control plasma, RCT was not significantly different whether HDL was isolated from patients with and without dementia and controls on a mol/mol basis (Fig. 3A). When cholesterol efflux was corrected to HDL concentration found in the plasma, RCT was significantly lower in the AD Plus group (Fig. 3B).

There was a tendency for HDL to be nitrated to a greater extent in the AD Plus group, however, there was no significant difference in HDL nitration or oxidation (Fig. 3C, F) nor were total plasma levels of 3-nitrotyrosine or protein carbonyl different between any of the subject groups studied (Fig. 3D, E).

\section{DISCUSSION}

Here we have shown for the first time that plasma HDL, lutein, and zeaxanthin concentrations are lower in the AD Plus patient group and thus their effective capacity in plasma to mediate RCT is lowered. MMSE 
A

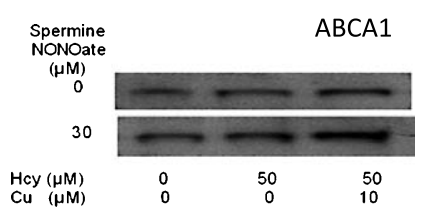

B

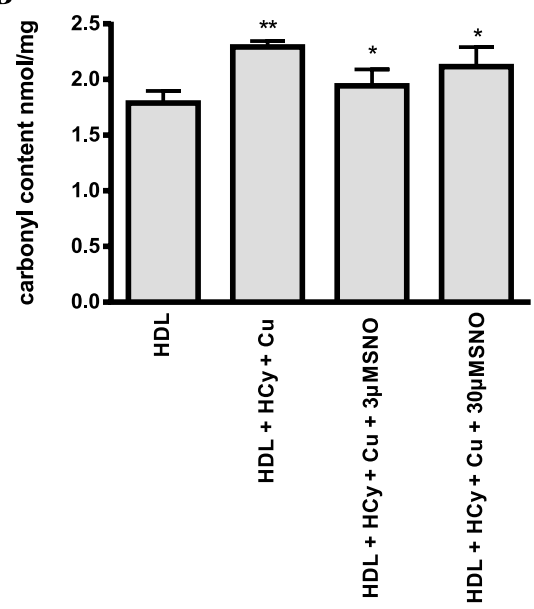

$\mathbf{C}$

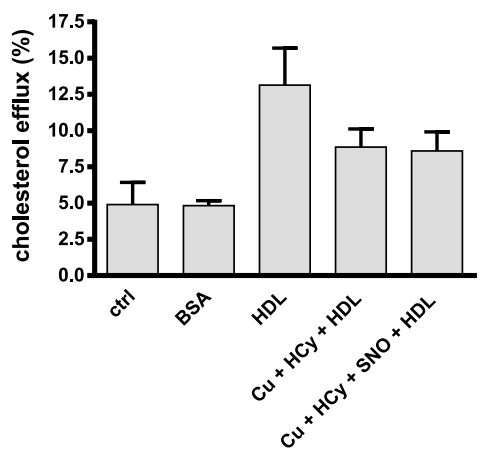

Fig. 2. Oxidized and nitrated HDL is less effective in reverse cholesterol transport. A) HDL treated with $30 \mu \mathrm{M}$ spermine NONOate (SNO), $10 \mu \mathrm{M}$ copper, and $50 \mu \mathrm{M}$ homocysteine (HCy) show the greatest increase in 3-nitrotyrosine level as determined by western blotting. B) HDL carbonyl content determined by ELISA was increased significantly by $\mathrm{HCy} / \mathrm{Cu}$ and this was attenuated in part by spermine NONOate. C) RCT measured as ${ }^{3} \mathrm{H}$-cholesterol efflux is impaired to nitrated and oxidized HDL. Differences were evaluated by ANOVA where ${ }^{*} p<0.05 ;{ }^{* *} p<0.01$.

correlated positively with plasma HDL, lutein, and zeaxanthin suggesting that increasing HDL cholesterol and increasing carotenoids may also improve cognitive outcomes for patients.

HDL plays a critical role in RCT within the systemic circulation, removing cholesterol from peripheral tissues for hepatic degradation. Disturbances in cholesterol metabolism are common to a number of pathologies which increase the risk for development of dementia in later life [34]. The present study demonstrates that HDL function and nitration levels are not different between patients with cognitive impairment and age-matched control subjects, but that in patients with $\mathrm{AD}$ and vascular comorbidities/risk factors the HDL levels are significantly lower.

Previous work has shown in a longitudinal study that lowering of HDL over five years associates with a significant decline in memory [35]. The InChianti study showed that among community-dwelling older people, those with dementia had significantly lower total cholesterol, non-HDL-cholesterol (HDL-C), and HDL-C levels; however, using multivariate analysis only low HDL-C was associated with dementia [16]. These results are consistent with our findings and suggest the existence of an independent relationship between the pathologic vascular component of $\mathrm{AD}$ and low HDL-C levels.

Peripheral cholesterol metabolism is considered to be completely separate from brain cholesterol metabolism, however, HDL can cross the bloodbrain barrier [36]. The mechanisms by which HDL may exert a protective effect include the assembly with A $\beta$ to mediate RCT [37], RCT from tissue via ABCA1-dependent pathways, and through delivery of carotenoids and tocopherols [35].

Many of the recently described functions of HDL are not strictly attributed to its capacity to promote cholesterol flux, but by the other molecules it transports. These include proteins, small RNAs, bioactive lipids, hormones, vitamins, and carotenoids [38, 39]. In chickens with ABCA1 deficiency, circulating HDL and carotenoid concentrations were low and tissue deposition of lutein was reduced to $5 \%$ of control animal tissue levels [40]. Another carotenoid, astaxanthin, has been described as an important inducer of ABCA1 expression in macrophages and plays an important role in movement of cholesterol to HDL [41]. A large percentage of the polar oxocarotenoids are found on HDL (lutein, 53\%; zeaxanthin and cryptoxanthin, 39\%) but while HDL only transports a small percentage of total plasma non-polar carotenoids (e.g., lycopene, 17\%; $\alpha$ carotene, 26\%; and $\beta$-carotene, 22\%) [38], it has been suggested that the content of $\beta$-carotene per unit lipid is greater in HDL than in LDL hence are likely to play an important role in protecting HDL from modification by free radicals [28]. Lowered HDL concentration is associated with reduced carotenoid transport which may influence the expression of proteins involved in RCT, e.g., ABCA1 [42].

In the present work, we show that the oxocarotenoids, lutein and zeaxanthin, and lycopene are significantly depleted in the plasma of patients in the 


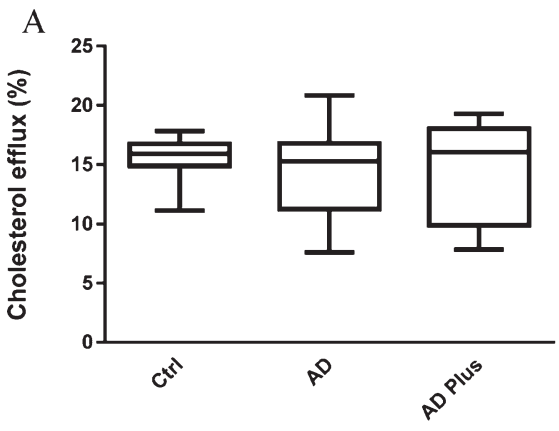

$\mathrm{C}$

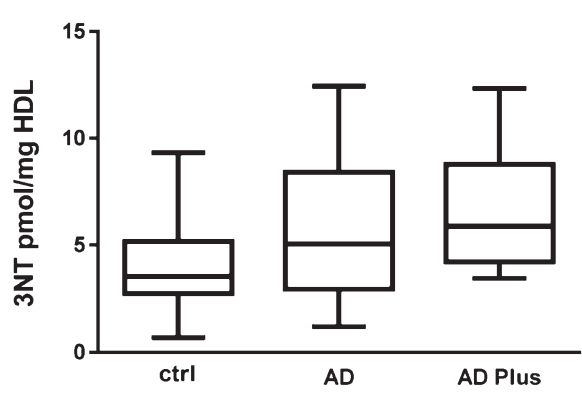

$\mathrm{E}$

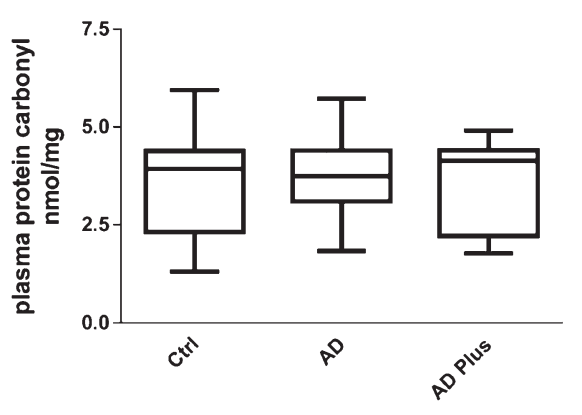

B

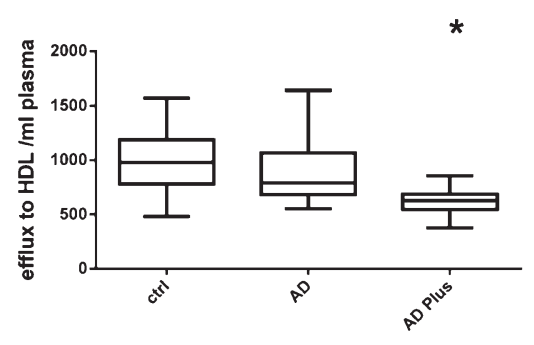

D

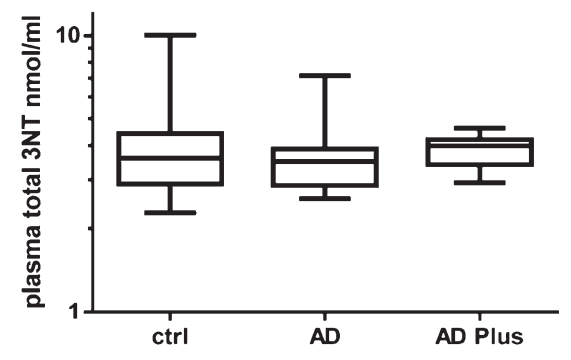

Fig. 3. HDL modification and function were not different between $\mathrm{AD}(n=28)$, AD plus $(n=16)$, and controls $(n=33)$. A) RCT measured as ${ }^{3} \mathrm{H}$-cholesterol efflux to equivalent molar HDL concentrations isolated from plasma. B) RCT measured as ${ }^{3} \mathrm{H}$-cholesterol efflux to HDL in plasma isolated from patients with and without dementia and controls. C) 3-nitrotyrosine (3NT) in HDL was determined by ELISA. D) 3-nitrotyrosine levels in plasma proteins were determined by ELISA. E) Plasma protein carbonyl levels were determined by ELISA. F) HDL carbonyl levels determined by ELISA. Differences were evaluated by ANOVA where ${ }^{*} p<0.05$.

AD Plus group and that their concentrations correlate with MMSE. This deficit remains for zeaxanthin and lutein even when adjusted for HDL cholesterol concentration. Hence either a decrease in HDL concentration or carotenoid concentration is expected to impact RCT independently. Carotenoids are powerful scavengers of singlet oxygen and so can prevent protein oxidation and nitration in vivo and in vitro [43-46]; there is a wealth of evidence for protein oxidation and nitration in the periphery and brain during cognitive impairment [29]. ApoA1, the major apoprotein in HDL, is susceptible to oxidation forming a bis-sulfoxide at methionines 112 and 148. This modification renders the molecule more susceptible to denaturation, 
reduces the formation of discoid dimeric and tetrameric aggregates which are essential for reverse cholesterol function, and favors formation of amyloid like fibrils $[47,48]$. HDL from atherosclerotic lesions and peripheral blood of patients with coronary artery disease also contain chlorinated, nitrated, and oxidized residues most likely arising from myeloperoxidase catalyzed oxidation. Others have shown that oxidation of $\mathrm{Met}^{148}$ to methionine sulfoxide was associated with loss of HDL RCT activity and Tyr ${ }^{192}$ was found to be the predominant site for nitration and chlorination when MPO or $\mathrm{ONOO}^{-}$were used to oxidize ApoA1; tyrosine chlorination and methionine oxidation markedly reduced the cholesterol efflux activity of ApoA1 [22, 23]. In the present study, we have shown that oxidation and nitration of HDL occur in parallel in the presence of spermine NONOate, homocysteine, and copper resulting in methionine oxidation at 86,112 , and 148 , nitration of $\mathrm{Tyr}^{192}$ and that RCT to HDL was impaired after modification. To explore whether the depletion of carotenoids in AD Plus patients was associated with tyrosine nitration or protein carbonyl formation, plasma HDL and total plasma proteins were analyzed by 3-nitrotyrosine and protein carbonyl ELISAs respectively. There was no significant increase in nitration of HDL in plasma from any of the patient groups with dementia when compared to control subjects. This differentiates dementia from general vascular diseases where HDL nitration is prevalent [19].

A recent study has shown that $\mathrm{RCT}$ to AD HDL is impaired when compared to age-matched control HDL [49]. Our present study does not confirm this earlier observation despite the sample size of $\mathrm{AD}$ and age-matched control groups being similar between the two studies. Unlike our AD Plus group, HDL concentrations in the plasma of AD patients in our study were not different from control subject serum HDL. However, in Khalil's study, HDL concentrations were lower in $\mathrm{AD}$ patients [49]. It is probable that the previous study did not discriminate between $\mathrm{AD}$ with and without vascular pathology.

In our AD Plus patients, 3-nitrotyrosine per HDL was $50 \%$ higher than for $\mathrm{AD}$ or control subjects; conversely carotenoids and HDL concentrations were significantly lower than in control subjects. Cholesterol export from tissue to plasma HDL and carotenoid transport to tissue is likely to be impaired in AD Plus based on plasma concentration alone. The importance of HDL as transporter of small regulatory molecules suggest that its depletion in dementia may have wider significance than for cholesterol metabolism alone [38].
Despite the wealth of evidence from cross-sectional and observational studies for an association between elevated serum cholesterol in mid-life and later development of $\mathrm{AD}$, there is insufficient understanding to recommend statin interventions to reduce disease risk, probably due to the significant role of individual lifehistory at particular ages and the lack of investigation in well-characterized sub-cohorts, e.g., AD Plus [10]. In some studies, statin therapy has been effective in modifying plasma lipids levels, but not adequate as a monotherapy to normalize the HDL subclass distribution phenotype [50]. In the field of coronary heart disease, interest is growing to elevate HDL cholesterol rather than just reducing total cholesterol to reduce risk of cardiovascular events [51]. The present data suggest that increasing HDL cholesterol and increasing carotenoids may also improve cognitive outcomes for patients. This effect may be achieved through increasing transport of carotenoids to tissues and promoting export of $A \beta$ and cholesterol from tissues. The relative importance of elevating HDL alone compared with elevating carotenoids alone or elevating both to reduce risk for dementia should be investigated in patients with early signs of dementia.

\section{ACKNOWLEDGMENTS}

This work was supported by The Dunhill Medical Trust [grant number: R92/1108]. LL gratefully acknowledges support from the German Academic Exchange programme. HRG, IHKD, TG, DW and HRG gratefully acknowledge financial support from COST CM1001.

Authors' disclosures available online (http://www.jalz.com/disclosures/view.php?id=2040).

\section{REFERENCES}

[1] Lozano R, Naghavi M, Foreman K, Lim S, Shibuya K, Aboyans V, Abraham J, Adair T, Aggarwal R, Ahn SY, Alvarado M, Anderson HR, Anderson LM, Andrews KG, Atkinson C, Baddour LM, Barker-Collo S, Bartels DH, Bell ML, Benjamin EJ, Bennett D, Bhalla K, Bikbov B, Bin Abdulhak A, Birbeck G, Blyth F, Bolliger I, Boufous S, Bucello C, Burch M, Burney P, Carapetis J, Chen H, Chou D, Chugh SS, Coffeng LE, Colan SD, Colquhoun S, Colson KE, Condon J, Connor MD, Cooper LT, Corriere M, Cortinovis M, de Vaccaro KC, Couser W, Cowie BC, Criqui MH, Cross M, Dabhadkar KC, Dahodwala N, De Leo D, Degenhardt L, Delossantos A, Denenberg J, Des Jarlais DC, Dharmaratne SD, Dorsey ER, Driscoll T, Duber H, Ebel B, Erwin PJ, Espindola P, Ezzati M, Feigin V, Flaxman AD, Forouzanfar MH, Fowkes FG, Franklin R, Fransen M, Freeman MK, Gabriel SE, Gakidou E, Gaspari F, Gillum RF, Gonzalez-Medina D, Halasa YA, Haring D, Harrison JE, Havmoeller R, Hay RJ, Hoen B, Hotez PJ, Hoy D, 
Jacobsen KH, James SL, Jasrasaria R, Jayaraman S, Johns N, Karthikeyan G, Kassebaum N, Keren A, Khoo JP, Knowlton LM, Kobusingye O, Koranteng A, Krishnamurthi R, Lipnick M, Lipshultz SE, Ohno SL, Mabweijano J, MacIntyre MF, Mallinger L, March L, Marks GB, Marks R, Matsumori A, Matzopoulos R, Mayosi BM, McAnulty JH, McDermott MM, McGrath J, Mensah GA, Merriman TR, Michaud C, Miller M, Miller TR, Mock C, Mocumbi AO, Mokdad AA, Moran A, Mulholland K, Nair MN, Naldi L, Narayan KM, Nasseri K, Norman P, O’Donnell M, Omer SB, Ortblad K, Osborne R, Ozgediz D, Pahari B, Pandian JD, Rivero AP, Padilla RP, Perez-Ruiz F, Perico N, Phillips D, Pierce K, Pope CA, 3rd, Porrini E, Pourmalek F, Raju M, Ranganathan D, Rehm JT, Rein DB, Remuzzi G, Rivara FP, Roberts T, De Leon FR, Rosenfeld LC, Rushton L, Sacco RL, Salomon JA, Sampson U, Sanman E, Schwebel DC, Segui-Gomez M, Shepard DS, Singh D, Singleton J, Sliwa K, Smith E, Steer A, Taylor JA, Thomas B, Tleyjeh IM, Towbin JA, Truelsen T, Undurraga EA, Venketasubramanian N, Vijayakumar L, Vos T, Wagner GR, Wang M, Wang W, Watt K, Weinstock MA, Weintraub R, Wilkinson JD, Woolf AD, Wulf S, Yeh PH, Yip P, Zabetian A, Zheng ZJ, Lopez AD, Murray CJ, AlMazroa MA, Memish ZA (2012) Global and regional mortality from 235 causes of death for 20 age groups in 1990 and 2010: A systematic analysis for the Global Burden of Disease Study 2010. Lancet 380, 2095-2128.

[2] Agüero-Torres H kM, von Strauss E (2006) Rethinking the dementia diagnoses in a population-based study: What is Alzheimer's disease and what is vascular dementia? A study from the Kungsholmen Project. Dement Geriatr Cogn Disord 22, 244-249.

[3] Bendlin BB, Carlsson CM, Gleason CE, Johnson SC, Sodhi A, Gallagher CL, Puglielli L, Engelman CD, Ries ML, $\mathrm{Xu} \mathrm{G}$, Wharton W, Asthana S (2010) Midlife predictors of Alzheimer's disease. Maturitas 65, 131-137.

[4] Crean S, Ward A, Mercaldi CJ, Collins JM, Cook MN, Baker NL, Arrighi HM (2011) Apolipoprotein E epsilon4 prevalence in Alzheimer's disease patients varies across global populations: A systematic literature review and meta-analysis. Dement Geriatr Cogn Disord 31, 20-30.

[5] Xiao Z, Wang J, Chen W, Wang P, Zeng H, Chen W (2012) Association studies of several cholesterol-related genes (ABCA1, CETP and LIPC) with serum lipids and risk of Alzheimer's disease. Lipids Health Dis 11, 163.

[6] Hollingworth P, Harold D, Sims R, Gerrish A, Lambert JC, Carrasquillo MM, Abraham R, Hamshere ML, Pahwa JS, Moskvina V, Dowzell K, Jones N, Stretton A, Thomas C, Richards A, Ivanov D, Widdowson C, Chapman J, Lovestone S, Powell J, Proitsi P, Lupton MK, Brayne C, Rubinsztein DC, Gill M, Lawlor B, Lynch A, Brown KS, Passmore PA, Craig D, McGuinness B, Todd S, Holmes C, Mann D, Smith AD, Beaumont H, Warden D, Wilcock G, Love S, Kehoe PG, Hooper NM, Vardy ERLC, Hardy J, Mead S, Fox NC, Rossor M, Collinge J, Maier W, Jessen F, Ruther E, Schurmann B, Heun R, Kolsch H, van den Bussche H, Heuser I, Kornhuber J, Wiltfang J, Dichgans M, Frolich L, Hampel H, Gallacher J, Hull M, Rujescu D, Giegling I, Goate AM, Kauwe JSK, Cruchaga C, Nowotny P, Morris JC, Mayo K, Sleegers K, Bettens K, Engelborghs S, De Deyn PP, Van Broeckhoven C, Livingston G, Bass NJ, Gurling H, McQuillin A, Gwilliam R, Deloukas P, Al-Chalabi A, Shaw CE, Tsolaki M, Singleton AB, Guerreiro R, Muhleisen TW, Nothen MM, Moebus S, Jockel K-H, Klopp N, Wichmann HE, Pankratz VS, Sando SB, Aasly JO, Barcikowska M, Wszolek ZK, Dickson DW, Graff-Radford NR, Petersen RC, van Duijn CM, Breteler
MMB, Ikram MA, DeStefano AL, Fitzpatrick AL, Lopez O, Launer LJ, Seshadri S, Berr C, Campion D, Epelbaum J, Dartigues J-F, Tzourio C, Alperovitch A, Lathrop M, Feulner TM, Friedrich P, Riehle C, Krawczak M, Schreiber S, Mayhaus M, Nicolhaus S, Wagenpfeil S, Steinberg S, Stefansson H, Stefansson K, Snaedal J, Bjornsson S, Jonsson PV, Chouraki V, Genier-Boley B, Hiltunen M, Soininen H, Combarros O, Zelenika D, Delepine M, Bullido MJ, Pasquier F, Mateo I, Frank-Garcia A, Porcellini E, Hanon O, Coto E, Alvarez V, Bosco P, Siciliano G, Mancuso M, Panza F, Solfrizzi V, Nacmias B, Sorbi S, Bossu P, Piccardi P, Arosio B, Annoni G, Seripa D, Pilotto A, Scarpini E, Galimberti D, Brice A, Hannequin D, Licastro F, Jones L, Holmans PA, Jonsson T, Riemenschneider M, Morgan K, Younkin SG, Owen MJ, O'Donovan M, Amouyel P, Williams J (2011) Common variants at ABCA7, MS4A6A/MS4A4E, EPHA1, CD33 and $\mathrm{CD} 2 \mathrm{AP}$ are associated with Alzheimer's disease. Nat Genet 43, 429-435.

[7] Ballard C, Gauthier S, Corbett A, Brayne C, Aarsland D, Jones E. Alzheimer's disease. Lancet 377, 1019-1031.

[8] Shepardson Ne SGMSDJ (2011) Cholesterol level and statin use in alzheimer disease: I. review of epidemiological and preclinical studies. Arch Neurol 68, 1239-1244.

[9] Li L, Willets RS, Polidori MC, Stahl W, Nelles G, Sies H, Griffiths HR (2010) Oxidative LDL modification is increased in vascular dementia and is inversely associated with cognitive performance. Free Radic Res 44, 241-248.

[10] McGuinness B, O'Hare J, Craig D, Bullock R, Malouf R, Passmore $P$ (2013) Cochrane review on 'Statins for the treatment of dementia'. Int J Geriatr Psychiatry 28, 119-126.

[11] Brown J, 3rd, Theisler C, Silberman S, Magnuson D, Gottardi-Littell N, Lee JM, Yager D, Crowley J, Sambamurti K, Rahman MM, Reiss AB, Eckman CB, Wolozin B (2004) Differential expression of cholesterol hydroxylases in Alzheimer's disease. J Biol Chem 279, 34674-34681.

[12] Heverin M, Bogdanovic N, Lutjohann D, Bayer T, Pikuleva I, Bretillon L, Diczfalusy U, Winblad B, Bjorkhem I (2004) Changes in the levels of cerebral and extracerebral sterols in the brain of patients with Alzheimer's disease. J Lipid Res $\mathbf{4 5}$, 186-193.

[13] Bjorkhem I (2006) Crossing the barrier: Oxysterols as cholesterol transporters and metabolic modulators in the brain. $J$ Intern Med 260, 493-508.

[14] Zhong N, Weisgraber KH (2009) Understanding the association of apolipoprotein E4 with Alzheimer disease: Clues from its structure. J Biol Chem 284, 6027-6031.

[15] Bodovitz S, Klein WL (1996) Cholesterol modulates alphasecretase cleavage of amyloid precursor protein. J Biol Chem 271, 4436-4440.

[16] Zuliani G, Cavalieri M, Galvani M, Volpato S, Cherubini A, Bandinelli S, Corsi AM, Lauretani F, Guralnik JM, Fellin R, Ferrucci L (2010) Relationship between low levels of highdensity lipoprotein cholesterol and dementia in the elderly. The InChianti study. J Gerontol A Biol Sci Med Sci 65, 559564.

[17] Cuchel M, Rader DJ (2006) Macrophage reverse cholesterol transport: Key to the regression of atherosclerosis? Circulation 113, 2548-2555.

[18] Fitz NF, Cronican AA, Saleem M, Fauq AH, Chapman R, Lefterov I, Koldamova R (2012) Abcal deficiency affects Alzheimer's disease-like phenotype in human ApoE4 but not in ApoE3-targeted replacement mice. J Neurosci 32, 1312513136.

[19] Zheng L, Nukuna B, Brennan ML, Sun M, Goormastic M, Settle M, Schmitt D, Fu X, Thomson L, Fox PL, Ischiropou- 
los H, Smith JD, Kinter M, Hazen SL (2004) Apolipoprotein A-I is a selective target for myeloperoxidase-catalyzed oxidation and functional impairment in subjects with cardiovascular disease. J Clin Invest 114, 529-541.

[20] Zheng L, Settle M, Brubaker G, Schmitt D, Hazen SL, Smith JD, Kinter M (2005) Localization of nitration and chlorination sites on apolipoprotein A-I catalyzed by myeloperoxidase in human atheroma and associated oxidative impairment in ABCA1-dependent cholesterol efflux from macrophages. $J$ Biol Chem 280, 38-47.

[21] Griffiths HR, Aldred S, Dale C, Nakano E, Kitas GD, Grant MG, Nugent D, Taiwo FA, Li L, Powers HJ (2006) Homocysteine from endothelial cells promotes LDL nitration and scavenger receptor uptake. Free Radic Biol Med 40, 488-500.

[22] Shao B, Bergt C, Fu X, Green P, Voss JC, Oda MN, Oram JF, Heinecke JW (2005) Tyrosine 192 in apolipoprotein A-I is the major site of nitration and chlorination by myeloperoxidase, but only chlorination markedly impairs ABCA1-dependent cholesterol transport. J Biol Chem 280, 5983-5993.

[23] Shao B, Cavigiolio G, Brot N, Oda MN, Heinecke JW (2008) Methionine oxidation impairs reverse cholesterol transport by apolipoprotein A-I. Proc Natl Acad Sci U S A 105, 1222412229.

[24] Polidori MC, Nelles G, Pientka L (2010) Prevention of dementia: Focus on lifestyle. Int J Alzheimers Dis 2010, pii: 393579.

[25] Obulesu M, Dowlathabad MR, Bramhachari PV (2011) Carotenoids and Alzheimer's disease: An insight into therapeutic role of retinoids in animal models. Neurochem Int 59, 535-541.

[26] Wang W, Shinto L, Connor WE, Quinn JF (2008) Nutritional biomarkers in Alzheimer's disease: The association between carotenoids, n-3 fatty acids, and dementia severity. J Alzheimers Dis 13, 31-38.

[27] Anlasik T, Sies H, Griffiths HR, Mecocci P, Stahl W, Polidori MC (2005) Dietary habits are major determinants of the plasma antioxidant status in healthy elderly subjects. BrJ Nutr 94, 639-642.

[28] R.S.P (1996) Absorption, metabolism and transport of carotenoids. FASEB J 10, 542-551.

[29] Polidori MC, Mattioli P, Aldred S, Cecchetti R, Stahl W, Griffiths H, Senin U, Sies H, Mecocci P (2004) Plasma antioxidant status, immunoglobulin $\mathrm{g}$ oxidation and lipid peroxidation in demented patients: Relevance to Alzheimer disease and vascular dementia. Dement Geriatr Cogn Disord 18, 265-270.

[30] Chung BH, Wilkinson T, Geer JC, Segrest JP (1980) Preparative and quantitative isolation of plasma lipoproteins: Rapid, single discontinuous density gradient ultracentrifugation in a vertical rotor. J Lipid Res 21, 284-291.

[31] Weber D, Kneschke N, Grimm S, Bergheim I, Breusing N, Grune T (2012) Rapid and sensitive determination of proteinnitrotyrosine by ELISA: Application to human plasma. Free Radic Res 46, 276-285.

[32] Stahl W, Schwarz W, Sundquist AR, Sies H (1992) cis-trans isomers of lycopene and beta-carotene in human serum and tissues. Arch Biochem Biophys 294, 173-177.

[33] Carty JL, Bevan R, Waller H, Mistry N, Cooke M, Lunec J, Griffiths HR (2000) The effects of vitamin C supplementation on protein oxidation in healthy volunteers. Biochem Biophys Res Commun 273, 729-735.

[34] de la Torre J (2012) Preface: Physiopathology of vascular risk factors in Alzheimer's disease. J Alzheimers Dis 32, 517-518.

[35] Singh-Manoux A, Gimeno D, Kivimaki M, Brunner E, Marmot MG (2008) Low HDL cholesterol is a risk factor for deficit and decline in memory in midlife: The Whitehall II study. Arterioscler Thromb Vasc Biol 28, 1556-1562.

[36] Balazs Z, Panzenboeck U, Hammer A, Sovic A, Quehenberger O, Malle E, Sattler W (2004) Uptake and transport of high-density lipoprotein (HDL) and HDL-associated $\alpha$-tocopherol by an in vitro blood-brain barrier model. $\mathrm{J} \mathrm{Neu}$ rochem $\mathbf{8 9}, 939-950$.

[37] Umeda T, Mori H, Zheng H, Tomiyama T (2010) Regulation of cholesterol efflux by amyloid beta secretion. J Neurosci Res 88, 1985-1994.

[38] Vickers KC, Remaley AT (2014) HDL and cholesterol: Life after the divorce? J Lipid Res 55, 4-12.

[39] Clevidence BA, Bieri JG (1993) [4] Association of carotenoids with human plasma lipoproteins. In Methods in Enzymology, Lester P, ed. Academic Press, pp. 33-46.

[40] Connor WE, Duell PB, Kean R, Wang Y (2007) The prime role of HDL to transport lutein into the retina: Evidence from HDL-deficient WHAM chicks having a mutant ABCA1 transporter. Invest Ophthalmol Vis Sci 48, 4226-4231.

[41] Iizuka M, Ayaori M, Uto-Kondo H, Yakushiji E, Takiguchi S, Nakaya K, Hisada T, Sasaki M, Komatsu T, Yogo M, Kishimoto Y, Kondo K, Ikewaki K (2012) Astaxanthin enhances ATP-binding cassette transporter A1/G1 expressions and cholesterol efflux from macrophages. J Nutr Sci Vitaminol (Tokyo) 58, 96-104.

[42] Palozza P, Catalano A, Simone RE, Mele MC, Cittadini A (2012) Effect of lycopene and tomato products on cholesterol metabolism. Ann Nutr Metab 61, 126-134.

[43] Sies H, Stahl W (1995) Vitamins E and C, beta-carotene, and other carotenoids as antioxidants. Am J Clin Nutr 62, 1315S$1321 \mathrm{~S}$.

[44] Fontana M, Blarzino C, Pecci L (2012) Formation of 3-nitrotyrosine by riboflavin photosensitized oxidation of tyrosine in the presence of nitrite. Amino Acids 42, 18571865.

[45] Graham DL, Carail M, Caris-Veyrat C, Lowe GM (2012) (13Z)- and (9Z)-lycopene isomers are major intermediates in the oxidative degradation of lycopene by cigarette smoke and Sin-1. Free Radic Res 46, 891-902.

[46] Panasenko OM, Briviba K, Klotz LO, Sies H (1997) Oxidative modification and nitration of human low-density lipoproteins by the reaction of hypochlorous acid with nitrite. Arch Biochem Biophys 343, 254-259.

[47] Sigalov AB, Stern LJ (2001) Oxidation of methionine residues affects the structure and stability of apolipoprotein A-I in reconstituted high density lipoprotein particles. Chem Physics Lipids 113, 133-146.

[48] Wong YQ, Binger KJ, Howlett GJ, Griffin MDW (2010) Methionine oxidation induces amyloid fibril formation by full-length apolipoprotein A-I. Proc Natl Acad Sci U S A 107, 1977-1982.

[49] Khalil A, Berrougui H, Pawelec G, Fulop T (2012) Impairment of the ABCA1 and SR-BI-mediated cholesterol efflux pathways and HDL anti-inflammatory activity in Alzheimer's disease. Mech Ageing Dev 133, 20-29.

[50] Tian L, Chen Y, Li C, Zeng Z, Xu Y, Long S, Fu M (2013) Statin treatment improves plasma lipid levels but not HDL subclass distribution in patients undergoing percutaneous coronary intervention. Lipids 48, 127-137.

[51] Rubenfire M, Brook RD (2013) HDL cholesterol and cardiovascular outcomes: What is the evidence? Curr Cardiol Rep 15,349 . 